\title{
marketing
}

\section{Helvetica as a Type Convention for the Youthful and Trendy Image: A Consumer Response to Designer Safe Option}

\author{
Uroš Nedeljković, Dragoljub Novaković, \\ Irma Puškarević, Ivana Tomić
}

\section{INTRODUCTION}

Most type practitioners and communication designer would agree that effective visual, and thus marketing, communication depends on a good type design and its proper application. Faced with a new challenge of the digital age, typography has a different role in graphic design, and we no longer see "typography as 'an abstract art' but as a means of communication in its own right" (van Leeuwen, 2006). In word-driven media, such as print advertising, typography is considered to be an important and obligatory element. Rowe (Rowe, 1982) believes this element to be a part of an analogic code of a message. According to Watzlawick, Beavin and Jackson (1967) analogic code is usually iconic and/or indexical, unlike the digital code that is usually represented by the words, transmitting the message's meaning. As such, a typeface can be analyzed and tested in relation to its connotative meaning primarily because the shape of the letters suggests, or rather implies an impression of convention. Wijnholds (1996) draws a parallel between Starkweather's (1956) two levels of communication in speech and the higher communication value in type. Similarly to how the spoken message content can be heightened by the speaker's voice, the written message content can be emphasized by the choice of the typeface. Consequently designers and scholars have displayed a great interest in typographic research regarding the emotional aspect in the attempt to improve the usability of typography.

Some of the earliest studies in typographic research investigated the feeling tone (Poffenberger and Franken, 1923; Davis and Smith, 1933; Kastl and Child, 1968). Subsequent studies were concerned about typeface appropriateness (Schiller, 1935; Brumberger, 2003a), impression management or connotative meaning (Tannenbaum et al., 1964; Henderson et al., 2004; Childers and Jass, 2002; Doyle and Bottomley, 2006; Morrison, 1986; Rowe, 1982), semantic quality of type (Bartram, 1982; Childers and Jass, 2002), persuasive effect (McCarthy and Mothersbaugh, 2002) and persona (Secrest, 1947; Brumberger, 2003b; Fox et al., 2007; Mackiewicz and Moeller, 2004). On the other hand, McCarthy and Mothersbaugh (2002) believe that print advertising executional elements can be matched with consumer's motivation opportunity and ability, hence the choice of a typeface can influence the persuasive effect of the message. In their view, this aspect has been neglected in research studies due to the lack of an organizing framework.
Abstract: In advertising, typography is considered an important and obligatory element. One of the most prominent typefaces of today is Helvetica, therefore it became the center of this research. The goal of this research was to examine the connotative meaning of the Helvetica typeface at the time of its renewed popularity. We tested the role of Helvetica as the basic component in relation to consumer response. The results indicate that emotional response to Helvetica is not higher when compared to other typefaces in advertisements suggesting this is not "an emotional typeface". However, we did find that subjects looked more favorably to advertisements which use Helvetica for showcasing the copy and the brand logo. We conclude that, even though Helvetica today, after its renewed popularity, represents a type convention for the youthful and trendy image, this typeface has not been assigned a new persuasive capacity.

Keywords: Advertising, typography, typeface, Helvetica, consumer response, emotional response, type convention. 
In short, most scholars and practitioners agree that the way typefaces are used in visual communication can evoke emotions and form opinions. However, this raises the question: Can we actually refer to a typeface as „an emotional typeface"? In their research, Henderson et al. (Henderson et al., 2004) face similar dilemma where they draw a parallel from the spokesperson research and look at the typeface design as a tool for 'dressing-up' the written word. Their findings illustrate how certain typeface design characteristics influence impressions we comprehend as formal, innovative, attractive, emotional, etc. Consequently, assigning human-like characteristics to fonts, suggesting their deeper meaning and character, typefaces represent a lot more than a simple message tool. Nevertheless, there are still some questions that stir our interest: is the affective response influenced by the type-specific design characteristics or can we say that some typefaces convey more, for example a specific convention, or even the brand value? To answer these questions, we conducted an empirical study with the most popular typeface of today, Helvetica, where the objective was to determine whether Helvetica is an element of preferable choice for 'good design' to communicate a certain convention. Helvetica is one of the most prominent and popular typefaces of our age. Therefore, the purpose of this paper was to determine is the use of this typeface all that justified. Through the course of this research, we analysed symbolic meaning of the Helvetica typeface, indicating the reasons for its popularity and continuous application.

\section{LITERATURE REVIEW AND RESEARCH QUESTIONS}

Empirical testing indicates there is a strong relationship between typography and emotions, suggesting that the influence of typography on attitude toward the brand, impression about the product and the company is measurable (Doyle and Bottomley, 2006; Henderson et al., 2004; Childers and Jass, 2002). Childers and Jass (2002) examined influence of typefaces on consumers' attitudes, brand perception and recall. It is confirmed that semantic associations of typefaces strongly influence brand perception. Analysing the interaction of the typeface with other elements of the advertisement, it was confirmed that the best brand recall is achieved if all elements (semantic associations of the typeface, visual and verbal register) are consistent and constant. Therefore, typography has a significant effect on consumers' perception and memory in marketing communication. Considering these findings, Childers and Jass (2002) assert that we should conceptualise typefaces as an independent ad element which transfers meaning since this approach is easier to perceive and place in the consumer's memory. These observations can be a starting point for further research. For example, if we examine one typeface from advertising surroundings, we can test its communicative power and connotative meaning.

In terms of typography, we can talk about two kinds of meaning, aesthetic meaning and meaning attributed by association (Wijnholds, 1996). The distinction goes further by dividing association into association of personality and, more importantly for the purposes of this research, association through convention. That is one of the many faces meaning can have and, unlike association of personality, convention is not based on shared features and the mood they evoke, but on an arbitrary link established by the frequency of use (Wijnholds, 1996). It is exactly why many typefaces that are already tied to a specific context e.g. the in lined slab serif college type or the or the well-known circus associated typeface, acquire their meaning by the context they have been used in over and over again, despite the fact that their formal attributes, style and origin have little to do with it. One such widely used and world famous iconic typeface is Helvetica. Considered to be neutral, its usage in almost every sphere of design or industry imaginable has given it a cult status and made it both a trend and a brand people opt for when they need a safe and secure choice of type.

\section{HELVETICA AS A TREND}

Helvetica is one of the elementary symbols of Modernism in design. Modernism is a direction of thought promotion which promotes the power of the human being to create, advance and shape its surroundings with the aid of scientific accomplishments and modern technology. In design, this style is characterized by clear and clean lines, organized grid, simplicity and a reduced amount of detail and elements. Modernism was always a symbol of innovation, future and progress.

By the end of the 1950s, Helvetica gained huge popularity entering the scene, and continued to maintain this status for more than a half of the $20^{\text {th }}$ century. There were of course fluctuations in its popularity, most noticeably during the 1960s and 1990s. In both periods, the designers were over-saturated with the monotony and omnipresence of Helvetica and the el- 
ements of Modernism; hence they wanted to find any kind of alternative solution. In their search, they went to the other end of the spectrum. In the 1960s and 1970s, designers promoted ornaments, spirals, fractals and a multitude of bright colours and hand lettering. During the 1990s in the Postmodernism era, designers opted for a chaotic, unorganized sequence of graphic elements that overlap using the most varied of means for designing a visual identity that was similar to everything else, except to what Helvetica represented. Still, at the end of Postmodernism, society turned to a different epoch. A sudden breakthrough in the development of the computer technologies gave an illusory image of the future. The emphasis was once again on the simplicity, efficiency and quick exchange of information. And what better way to transfer these qualities than by using Helvetica. The simplicity and the very clear rules of the Modernist design greatly benefited the self-proclaimed and self-taught designers and artists. All that was required was to follow a simple set of rules and instructions, and produce a high-quality design product. With the aid of modern technology and the usage of Helvetica it was as if you were exclaiming: "I am modern, I am the future!"

At the same time, the market became flooded with products marked by Helvetica. Although it never disappeared and its popularity has changed over the years, it was always present in some measure of consumer life. However, never like today was an individual more aware of its presence and consciously chose exactly the products that featured Helvetica within their logotype or advertisement.

According to Jeffery Keedy $(1995,2003)$ designers of today are guided solely by the requirements of the consumer, without greater thought or effort, accept already tried ideas using Helvetica, of course, as their primary tool of expression. On the other hand, the buyers, consumers and general public welcome anything that has been served without complaint. He also believes that styles and typefaces that are considered classical gained that status only because by using them, one decreases their chances of creating a bad design product and embarrassing oneself (Keedy, 1995). Seeing how no one wants to take risks, everybody turns to the simplest solution (Keedy, 1995).

Helvetica becomes a signifier which stated that the product in question was exactly the product of the future. A typeface that has crawled through all aspects of life throughout the years as neutral and unnoticeable, now comes into the foreground as the only and rational choice in graphic design. Helvetica became a trend, dictating the rules of graphic design. From packaging, print media, advertising, posters, street signs and television, it is everywhere.

With its 50th year of existence in 2007, Helvetica gained it's film. A documentary directed by Gary Hustwit is homage to this typeface and all it represents. At that moment, Helvetica became a star. Just as a person would, it acquired human traits and a fan club. It was not a tool for conveying a message anymore, it became the message itself. Helvetica became a symbol for the modern and broadminded, globally aware man facing the future and technology. It is found on clothing, kitchen utensils and office stationary, in the form of furniture, decoration and jewelry(Hustwit, 2007). It appears that there was no more a meaningful message; all that matters is that it was written out with Helvetica. This phenomenon is something which reflects the aspect of brand culture. The consumers are bound to the brand on an emotional level and there is a strong symbolic value of the brand for the consumers.

\section{THE PURPOSE OF THIS RESEARCH}

It has been noticed in the recent years that ubiquitous Helvetica typeface has become popular choice for a group of products targeted at younger generations. Specifically, we can see this typeface to be used over and over again for the brand logo and print advertising in fashion industry. The companies branded with Helvetica mostly target younger generations which is well aware of the Helvetica's symbolic meaning and the significance of its recognition.

Considering Helvetica's presence in the visual communication, empirical questions are postulated as to how this typeface influences the formation of the consumer attitude toward a brand or ad.

Through this research we have tried to determine whether or not there is a demographic profile to which a product containing Helvetica could always be "sold to" (RQ1), as well as (RQ2) what is the Helvetica'a influence to a wider range of consumers?

The communication model in ad attitude theory developed by Holbrook and Batra (1987) proposes that certain advertising content evokes emotional reaction which in turn formulates an attitude toward the ad. This attitude toward the ad influences the attitude toward the brand. Once the effectiveness of the attitudes is measured we find that advertisements have better results than the others. The model suggests positive linear flow of the ads influence through intervening variables on the attitude toward the brand. Consequently, a question is left open weather this ad content 
and emotional reaction will produce additional direct influences above and beyond their indirect influences through intervening mediators. In order to explain the extensive use of the Helvetica in print promotion design, we analyse the role of Helvetica as the basic component in regards to the positive emotional response of the consumers. Also, in the interest of exploring the influence of Helvetica to forming the brand image, we analyse the elements of the attitude toward the ad and the attitude toward the brand.

\section{EXPERIMENT}

A survey with 60 subjects was conducted in order to define whether the use of Helvetica in designing the ad and brand logo and ad have any impact on consumer's responses. Twenty three women and thirty seven men age range from 15-35 participated in this survey. Among them, 35 didn't have any formal knowledge of design and typography, while 25 had some basic or advanced knowledge. In the rest of the text, due to the simplification of notation, the first group of subjects would be addressed as "non-experienced", while the second would be named "experienced". All the subjects were naive to the purpose of the testing.

For this survey 20 ads were chosen from the categories of sporting goods for extreme sports equipment, shoes, denim and ready-wear (5 ads in each category). Ads were related to the brands known and available to the customers in Serbia. From the aspect of graphic design, the ads were selected with the intent that typography is the dominant element with regard to illustrations, photographs and other graphic elements. Research findings show that colour has a significant influence on people's emotions (Vandewalle et al., 2010; Valdez and Mehrabian, 1994) and also to preferences (Kaya and Epps, 2004), hence all the ads were converted to greyscale in order to exclude the effect of colour to subject's response.

In each group there was one ad with Helvetica and four ads where other typefaces were used. All the ads formed with Helvetica were created for the brands that contain the same typeface in their logo. The only exception was an ad in denim category where brand logo was not designed with Helvetica. To subjects the ads were presented on calibrated monitor.

Before the survey started subjects were asked to enter their gender, age and existence of previous knowledge in the fields of graphic design and typography. The assessment test had been designed in a way that subjects view one particular ad and after that fill the corresponding rating scales (each ad is followed by rating scales). Subjects assessed ads in computer-scorable booklet.

The aim of these assessments was to evaluate the subject's emotional response and preferences. For the emotions assessment Self-Assessment Manikin, SAM scales was used ${ }^{1}$. This scales refers to 3-dimensional structures: pleasure, arousal and dominance, model defined by Russell and Mehrabian (1977). Pleasure is covering emotions from pleasant to unpleasant, arousal is the scale from sleepy to frenetic excitement and dominance is showing control over some emotion (Lang, 1980). For the purpose of this testing SAM scale with 7 figures was chosen, where value of 1 indicated the weakest emotion, 4 -indifference and 7 the strongest emotion. Subjects were also asked to rate their attitude toward the ad and the brand. The answers are given in the form of degree of compliance with the statements "I like" and "I prefer". The degree of compliance is formed in the same manner as the SAM scale: 1 indicates no preference or likes, 4 indicates indifference, 7 indicates that the add is the most preferable and liked.

All the subjects were introduced with the meaning of the SAM scale and they were given the instruction on how to fill the scale according to their emotions. Subjects were not time limited. However, they were instructed to respond to the rating scales immediately after viewing the ad in order to limit the influence of cognition in emotional response.

All the responses were recorded and SPSS software was used for data processing. In order to determine the significance of Helvetica influence on subject's emotional response and preferences we used two-way multivariate repeated measurement analysis of covariance (MANCOVA). Dependent variables were pleasure, arousal and dominance, while independent variables were gender and formal knowledge of design and typography. As repeated measurements responses obtained from two groups of ads in each category were taken - first were responses obtained when an ad that contained Helvetica was assessed, while the second were responses to an ad without Helvetica. Since four ads without Helvetica were presented in each category, mean of the responses for each subject was used as "second measurement". The relations within

\footnotetext{
Self-Assessment Manikin (SAM), developed by Lang (1980), has been used effectively to measure emotional responses reactions to: pictures, images, sounds etc. (Bradley \& Lang, 1994), advertisements (Morris et al., 2002), visual content and codes in advertisements (Author 2013; 2011; Author 2013; Lang A, 2003).
} 
variables are observed within subjects (as a reactions to the certain ad) and also within groups (dividing the subjects according to gender and existence of formal knowledge of graphic design). Since there were three dependent variables, significance level was set to 0.017 . MANCOVA was performed for the responses to ads in each of defined categories (sporting goods and extreme sports equipment, shoes, denim and ready-wear) and for all the ads used in the survey.

For evaluating the preference toward the ad and the brand it was important to determine whether the usage of Helvetica in ad and brand logo design had any impact on attitude toward ad and brand. For that purpose results obtained from rating the preference (the scale I like-I do not like) were used. Mean values for each subject and each category were taken into account. Ad created with Helvetica in the category of denim was the only one that didn't have Helvetica in brand logo too, hence the results of the preference assessment of denim ads were left out when the influence of brand font on preference was evaluated. Two-way multivariate repeated measurement analysis of covariance (MANCOVA) was calculated where dependent variables were attitude toward brand and an ad, while as independent we defined gender formal knowledge of design and typography. As repeated measurements responses to ads with and without $\mathrm{Hel}-$ vetica were used.

When assessing the attitudes it was also important to determine whether there is some relation between attitude toward the ad and attitude toward the brand, that is, whether preferences to some brand influences the preference toward the ad of a certain brand. To estimate the possible relation Pearson correlation coefficient is determined between the rates given to an ad and the appropriate brand. For this analysis results obtained from rating the preference in form I prefer-I do not preferwere used. Correlation was determined for ads with and without Helvetica in total and for each ad category separately.

The results of emotional response and preferences, along with the discussion, are presented in the next section.

\section{RESULTS AND DISCUSSION}

\section{Results of emotional response assessment}

If all the ads are taken into account combined effects showed that there is no significant difference if man and women evaluated the ads with or without Helvet- ica $(F(3,54)=2.91, p=0.043$, eta squared $=0.139)$. Same stands for experienced and non-experienced subjects $(\mathrm{F}(3,54)=2.46, \mathrm{p}=0.072$, eta squared $=0.121)$.

If pleasure, arousal and dominance results are observed separately for all ads, it was noticed that subjects rated ads with and without Helvetica differently. Highest differences are noticed when rating pleasure $(\mathrm{F}(1,56)=18.94, \mathrm{p}<0.001)$, then dominance $(\mathrm{F}(1,56)=8.69, \mathrm{p}=0.05)$ and smallest, yet significant difference, was noticed for arousal grades $(F(1,56)=6.97$, $p=0.011$ ). Ads without Helvetica were rated better for each emotion. Mean rate for all the Helvetica ads were $4.28(\mathrm{SD}=1.26)$, while for ads without Helvetica it was $5.11(\mathrm{SD}=1.2)$. Same trend was noticed in each category (Table 1).

TABLE 1. Mean rates for ads with and without Helvetica for each emotion assessed

\begin{tabular}{l|c|c|}
\hline $\begin{array}{l}\text { Rated } \\
\text { emotion }\end{array}$ & $\begin{array}{c}\text { Mean rate for } \\
\text { Helvetica ad }\end{array}$ & $\begin{array}{c}\text { Mean rate for ads } \\
\text { without Helvetica }\end{array}$ \\
\hline Pleasure & $4.28(S D=1.26)$ & $5.11(S D=1.20)$ \\
\hline Arousal & $3.76(S D=1.56)$ & $4.29(S D=1.46)$ \\
\hline Dominance & $3.72(S D=1.15)$ & $4.33(S D=1.09)$ \\
\hline
\end{tabular}

Since it was noted that gender had an impact on reaction to the ad, rates for certain emotion given by men and women are also assessed. When evaluating pleasure, women had a tendency to give higher rates to ads without Helvetica, while men rate all the ads in the same manner (Figure 1).

Subjects with former knowledge in the field of typography showed statistically significant difference in ratings for the dimension arousal $(\mathrm{F}(1,56)=7.12$, $\mathrm{p}=0.010)$. In this case, experienced subjects were indifferent to the usage of Helvetica; while non-experienced found ads without Helvetica more exciting (Figure 2).

In the category of sporting goods for extreme sports equipment it was noticed that typeface had a significant influence on each rated emotion (pleasure $\mathrm{F}(1,56)=149.115, \mathrm{p}<0.0005$; arousal $-\mathrm{F}(1,56)=114.887$, $\mathrm{p}<0.0005$; domination $-\mathrm{F}(1,56)=32.839, \quad \mathrm{p}<0.0005)$. Gender and formal knowledge in typography did not have any significant impact on emotional response. In this category subjects rated ads with Helvetica better than those without, for each emotion assessed (Table 2). 

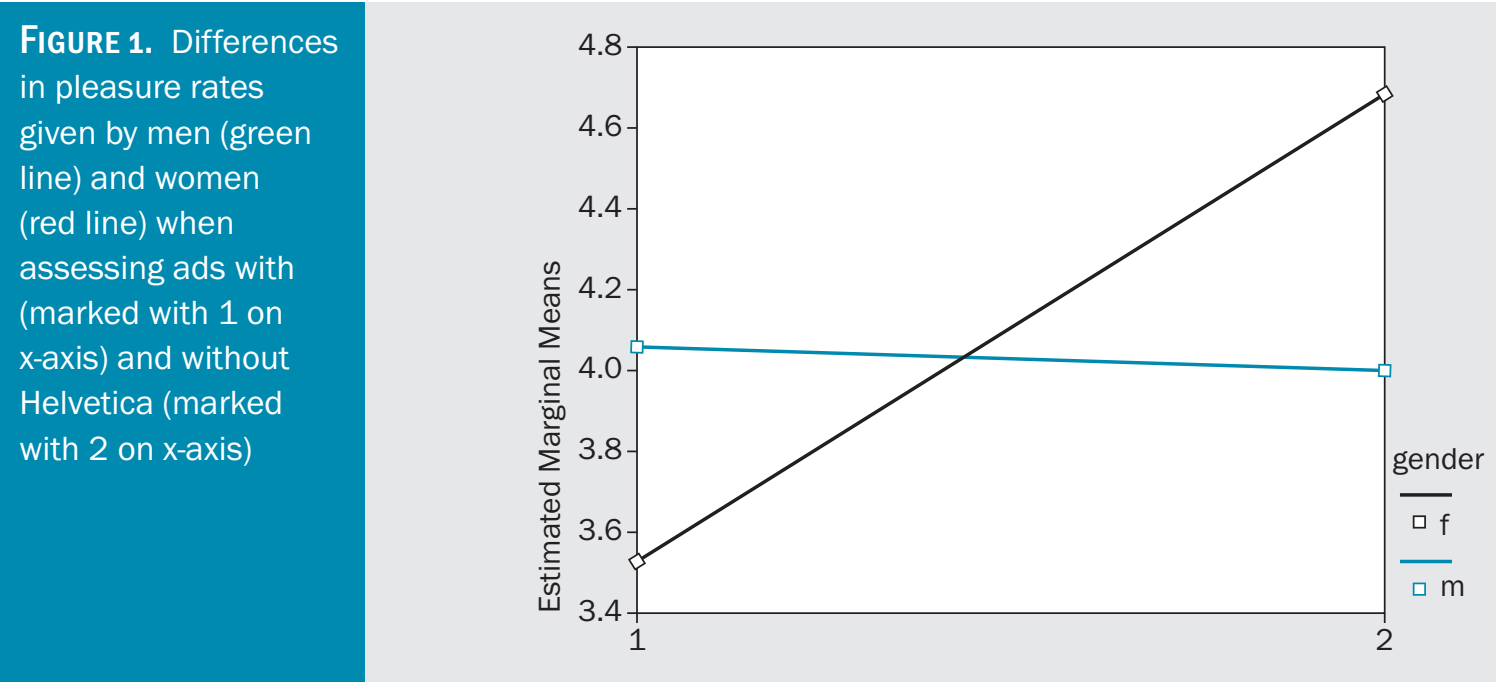

TABLE 2. Mean rates for ads with and without Helvetica for each emotion assessed for the extreme sports category

\begin{tabular}{l|c|c|}
\hline $\begin{array}{l}\text { Rated } \\
\text { emotion }\end{array}$ & $\begin{array}{c}\text { Mean rate for } \\
\text { Helvetica ad }\end{array}$ & $\begin{array}{c}\text { Mean rate for ads } \\
\text { without Helvetica }\end{array}$ \\
\hline Pleasure & $5.33(\mathrm{SD}=0.89)$ & $3.74(\mathrm{SD}=0.93)$ \\
\hline Arousal & $5.00(\mathrm{SD}=1.29)$ & $3.44(\mathrm{SD}=1.01)$ \\
\hline Dominance & $4.07(\mathrm{SD}=1.22)$ & $3.08(\mathrm{SD}=0.94)$ \\
\hline
\end{tabular}

When ads for shoes were assessed there were no statistically significant differences in subject emotional response to ads with or without Helvetica. Gender and former knowledge were also shown not to have any impact on the emotional response to certain ad.

When assessing ads for denim it was noticed that the gender $(\mathrm{F}(3,54)=3.98, \mathrm{p}=0.012)$ and ad type $(\mathrm{F}(1,54)=4.67, \mathrm{p}=0.006)$ had a significant impact on emotional response. Type used in the ad (i.e. whether Helvetica was used for designing the ad or not) had an impact only to pleasure. Ads with Helvetica were rated better $(M=4.37, S D=1.288)$, then those with other typefaces $(\mathrm{M}=4.07, \mathrm{SD}=1.089)$. In this category it was also noticed that combined interaction of ad type, gender and former knowledge had a significant impact on emotional response $(\mathrm{F}(3,54)=5,11, \mathrm{p}=0.003)$. When assessing the pleasure, highest rates were given by women subjects without formal typographical knowledge to the ads with Helvetica (Table 3). Same stands for arousal and domination. Lowest rates were given to the ads with Helvetica by men subjects without formal typographical knowledge (Table 3 ).

Differences in pleasure rates are more noticeable for experienced, then for non-experienced subjects, particularly for women (Figure 3).
FiguRE 2. Differences

in arousal rates given

by non-experienced

(green line) and

experienced subjects

(red line) when

assessing ads with

(marked with 1 on

$x$-axis) and without

Helvetica (marked

with 2 on $x$-axis)

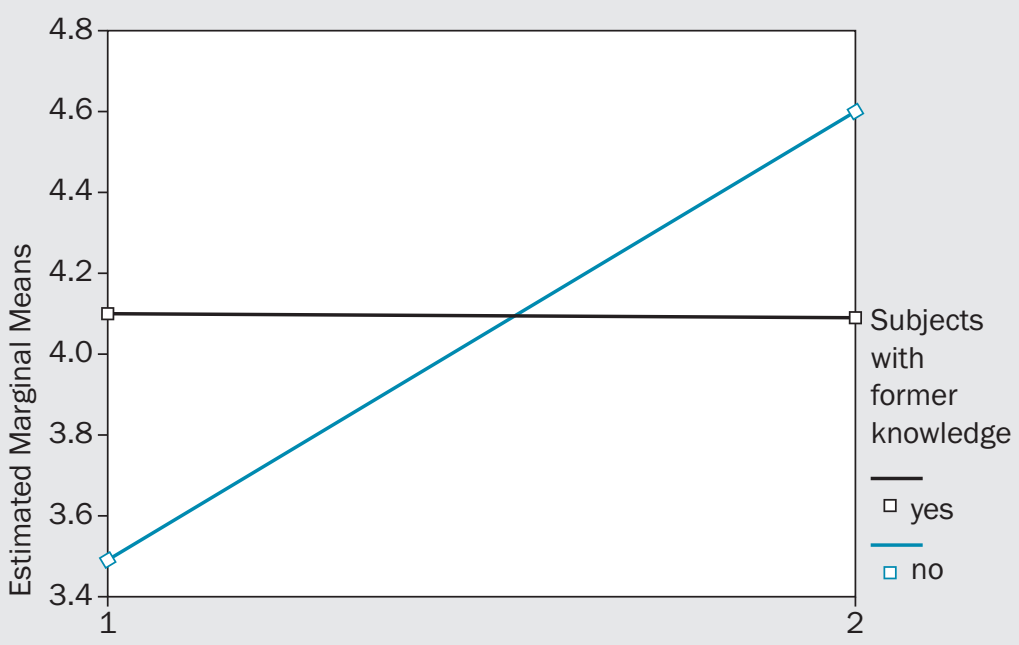




\section{marketing}

TABLE 3. Mean rates for pleasure, arousal and dominance given by men and women, with and without formal knowledge of typography for the denim category

\begin{tabular}{|c|c|c|c|c|c|c|c|}
\hline \multirow{2}{*}{ Measure } & \multirow{2}{*}{ Gender } & \multirow{2}{*}{ Experienced } & \multirow{2}{*}{ Helvetica } & \multirow{2}{*}{ Mean } & \multirow{2}{*}{ Std.Error } & \multicolumn{2}{|c|}{ 95\% Confidence Interval } \\
\hline & & & & & & Lower Bound & Upper Bound \\
\hline \multirow[t]{8}{*}{ Pleasure } & \multirow[t]{4}{*}{$\mathrm{F}$} & Yes & 1 & 4.364 & .342 & 3.679 & 5.048 \\
\hline & & & 2 & 4.523 & .328 & 3.866 & 5.180 \\
\hline & & No & 1 & 5.500 & .327 & 4.845 & 6.155 \\
\hline & & & 2 & 4.083 & .314 & 3.455 & 4.712 \\
\hline & \multirow[t]{4}{*}{ M } & Yes & 1 & 4.500 & .303 & 3.893 & 5.107 \\
\hline & & & 2 & 4.143 & .291 & 3.561 & 4.725 \\
\hline & & No & 1 & 3.696 & .236 & 3.222 & 4.169 \\
\hline & & & 2 & 3.815 & .227 & 3.361 & 4.269 \\
\hline \multirow[t]{8}{*}{ Arousal } & \multirow[t]{4}{*}{$\mathrm{F}$} & Yes & 1 & 3.818 & .419 & 2.978 & 4.658 \\
\hline & & & 2 & 4.000 & .329 & 3.341 & 4.659 \\
\hline & & No & 1 & 4.500 & .402 & 3.696 & 5.304 \\
\hline & & & 2 & 3.813 & .315 & 3.181 & 4.444 \\
\hline & \multirow[t]{4}{*}{ M } & Yes & 1 & 3.143 & .372 & 2.398 & 3.888 \\
\hline & & & 2 & 3.286 & .292 & 2.701 & 3.870 \\
\hline & & No & 1 & 3.000 & .290 & 2.419 & 3.581 \\
\hline & & & 2 & 3.413 & .228 & 2.957 & 3.869 \\
\hline \multirow[t]{8}{*}{ Dominance } & \multirow[t]{4}{*}{$\mathrm{F}$} & Yes & 1 & 3.636 & .431 & 2.772 & 4.500 \\
\hline & & & 2 & 4.273 & .311 & 3.649 & 4.896 \\
\hline & & No & 1 & 5.167 & .413 & 4.339 & 5.994 \\
\hline & & & 2 & 4.104 & .298 & 3.507 & 4.701 \\
\hline & \multirow[t]{4}{*}{ M } & Yes & 1 & 3.429 & .382 & 2.663 & 4.194 \\
\hline & & & 2 & 3.607 & .276 & 3.054 & 4.160 \\
\hline & & No & 1 & 3.043 & .298 & 2.446 & 3.641 \\
\hline & & & 2 & 3.481 & .215 & 3.050 & 3.912 \\
\hline
\end{tabular}

In the category of ready-wear ads it was noticed that ad type $(\mathrm{F}(3,54)=7.67, \mathrm{p}<0.0005)$, together with an interaction of gender $(F(3,54)=3.85, \mathrm{p}=0.014)$ had a significant impact on emotional response to ads. The usage of Helvetica in ad design had an impact on pleasure $(\mathrm{F}(1,54)=19.06, \mathrm{p}<0.0005)$ and arousal $(\mathrm{F}(1,54)=6.97, \mathrm{p}=0.011)$, while dominance was not affected. Ads without Helvetica were globally better rated (Table 4).

FIGURE 3. Differences in pleasure rates given by men (green line) and women (red line) when assessing ads with (marked with 1 on $\mathrm{x}$-axis) and without Helvetica (marked with 2 on $\mathrm{x}$-axis)

a. Experienced respondents

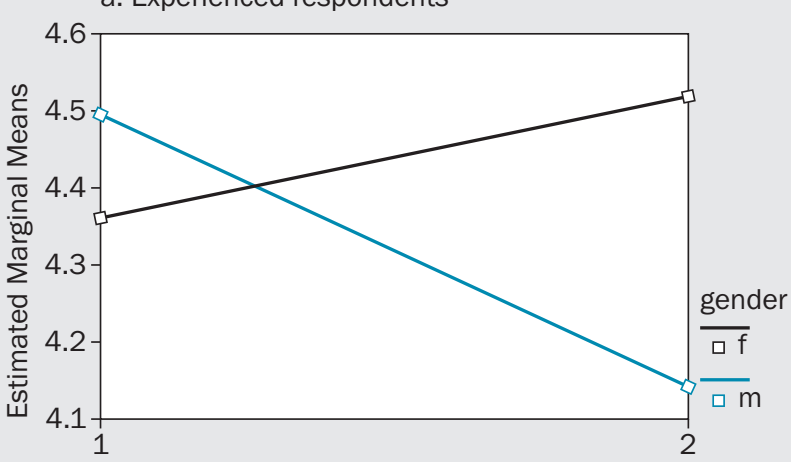

b. Non - experienced respondents

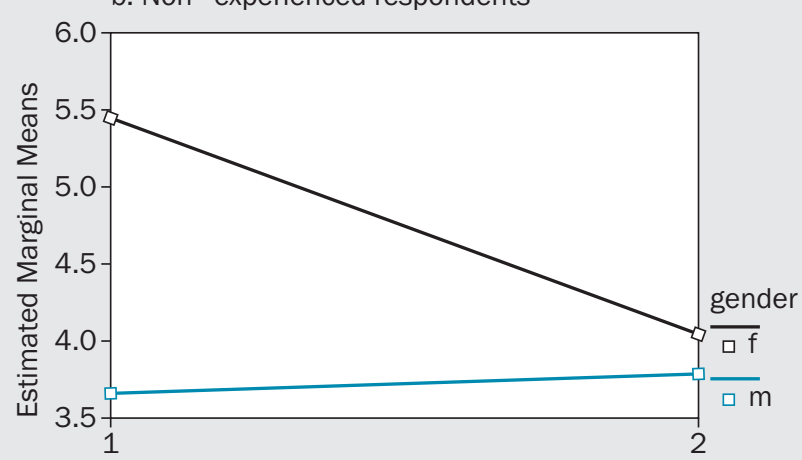


TABLE 4. Mean rates for ads with and without Helvetica for each emotion assessed for the ready-wear category

\begin{tabular}{l|c|c|}
$\begin{array}{l}\text { Rated } \\
\text { emotion }\end{array}$ & $\begin{array}{c}\text { Mean rate for } \\
\text { Helvetica ad }\end{array}$ & $\begin{array}{c}\text { Mean rate for ads } \\
\text { without Helvetica }\end{array}$ \\
\hline Pleasure & $4.28(S D=1.26)$ & $5.11(S D=1.20)$ \\
\hline Arousal & $3.77(S D=1.56)$ & $4.29(S D=1.47)$ \\
\hline Dominance & $3.71(S D=1.51)$ & $3.80(S D=1.68)$ \\
\hline
\end{tabular}

The interaction of the ad type and gender affected pleasure only. When ads with Helvetica were assessed men generally gave higher rates than women (mean rates given by men were $\mathrm{M}=3.91, \mathrm{SD}=1.68$ comparing with women rates $\mathrm{M}=3.52, \mathrm{SD}=1.34$ ). On the other hand, women rated better ads without Helvetica $(\mathrm{M}=4.69, \mathrm{SD}=1.48$ for women comparing withM=4.04, $\mathrm{SD}=1.41$ for men).

\section{Results of preference assessment}

Assessment of preferences gave an answer to a question whether the use of Helvetica in ad had any influence on an attitude toward the ad and corresponding brand. Following the results of MANCOVA analysis it was shown that the presence of Helvetica had actual impact on ad and brand preference, while gender and

TABLE 5. The results of multivariate analysis of covariance

\begin{tabular}{|c|c|c|c|c|c|c|c|}
\hline & \multirow{2}{*}{ Effect } & \multicolumn{6}{|c|}{ Hypothesis } \\
\hline & & & Value & $\mathbf{F}$ & df & Error df & Sig. \\
\hline \multirow{16}{*}{$\begin{array}{l}\text { Between } \\
\text { Subjects }\end{array}$} & \multirow[t]{4}{*}{ Intercept } & Pillai's Trace & .991 & $2961.768^{b}$ & 2.000 & 55.000 & .000 \\
\hline & & Wilks‘ Lambda & .009 & $2961.768^{b}$ & 2.000 & 55.000 & .000 \\
\hline & & Hotelling‘s Trace & 107.701 & $2961.768^{b}$ & 2.000 & 55.000 & .000 \\
\hline & & Roy‘s Largest Root & 107.701 & $2961.768^{b}$ & 2.000 & 55.000 & .000 \\
\hline & \multirow[t]{4}{*}{ Gender } & Pillai`s Trace & .026 & $.747^{b}$ & 2.000 & 55.000 & .478 \\
\hline & & Wilks‘ Lambda & .974 & $.747^{b}$ & 2.000 & 55.000 & .478 \\
\hline & & Hotelling‘s Trace & .027 & $.747^{b}$ & 2.000 & 55.000 & .478 \\
\hline & & Roy‘s Largest Root & .027 & $.747^{b}$ & 2.000 & 55.000 & .478 \\
\hline & \multirow[t]{4}{*}{ Experienced } & Pillai‘s Trace & .070 & $2.059^{b}$ & 2.000 & 55.000 & .137 \\
\hline & & Wilks‘ Lambda & .930 & $2.059^{b}$ & 2.000 & 55.000 & .137 \\
\hline & & Hotelling‘s Trace & .075 & $2.059^{b}$ & 2.000 & 55.000 & .137 \\
\hline & & Roy‘s Largest Root & .075 & $2.059^{b}$ & 2.000 & 55.000 & .137 \\
\hline & \multirow{4}{*}{$\begin{array}{l}\text { Gender* } \\
\text { Experienced }\end{array}$} & Pillai`s Trace & .030 & $.863^{b}$ & 2.000 & 55.000 & .428 \\
\hline & & Wilks‘ Lambda & .970 & $863^{b}$ & 2.000 & 55.000 & .428 \\
\hline & & Hotelling‘s Trace & .031 & $863^{b}$ & 2.000 & 55.000 & .428 \\
\hline & & Roy‘s Largest Root & .031 & $.863^{b}$ & 2.000 & 55.000 & .428 \\
\hline \multirow{16}{*}{$\begin{array}{l}\text { Within } \\
\text { Subjects }\end{array}$} & \multirow[t]{4}{*}{ Helvetica } & Pillai‘s Trace & .125 & $3.935^{b}$ & 2.000 & 55.000 & .025 \\
\hline & & Wilks‘ Lambda & .875 & $3.935^{b}$ & 2.000 & 55.000 & .025 \\
\hline & & Hotelling“s Trace & .143 & $3.935^{b}$ & 2.000 & 55.000 & .025 \\
\hline & & Roy‘s Largest Root & .143 & $3.935^{b}$ & 2.000 & 55.000 & .025 \\
\hline & \multirow{4}{*}{$\begin{array}{l}\text { Helvetica* } \\
\text { Gender }\end{array}$} & Pillaiłs Trace & .040 & $1.159^{b}$ & 2.000 & 55.000 & .321 \\
\hline & & Wilks‘ Lambda & .960 & $1.159^{b}$ & 2.000 & 55.000 & .321 \\
\hline & & Hotelling“s Trace & .042 & $1.159^{b}$ & 2.000 & 55.000 & .321 \\
\hline & & Roy‘s Largest Root & .042 & $1.159^{b}$ & 2.000 & 55.000 & .321 \\
\hline & \multirow{4}{*}{$\begin{array}{l}\text { Helvetica* } \\
\text { Experienced }\end{array}$} & Pillai's Trace & .019 & $.536^{\mathrm{b}}$ & 2.000 & 55.000 & .588 \\
\hline & & Wilks‘ Lambda & .981 & $.536^{\mathrm{b}}$ & 2.000 & 55.000 & .588 \\
\hline & & Hotelling،s Trace & .019 & $.536^{b}$ & 2.000 & 55.000 & .588 \\
\hline & & Roy‘s Largest Root & .019 & $.536^{\mathrm{b}}$ & 2.000 & 55.000 & .588 \\
\hline & \multirow{4}{*}{$\begin{array}{c}\text { Helvetica* } \\
\text { Gender* } \\
\text { Experienced }\end{array}$} & Pillaiłs Trace & .027 & $.763^{b}$ & 2.000 & 55.000 & .471 \\
\hline & & Wilks‘ Lambda & .973 & $763^{b}$ & 2.000 & 55.000 & .471 \\
\hline & & Hotelling“s Trace & .028 & $.763^{b}$ & 2.000 & 55.000 & .471 \\
\hline & & Roy‘s Largest Root & .023 & $.763^{\mathrm{b}}$ & 2.000 & 55.000 & .471 \\
\hline
\end{tabular}


former typographical knowledge didn't have any impact (Table 5).

In order to estimate the effects of Helvetica presence to individual preferences, the results of univariate analysis were assessed. It was noticed that the Helvetica in ad had a significant influence on ad preference $(\mathrm{F}(1,56)=5.81, \mathrm{p}=0.019)$, while it didn't influenced brand preference $(\mathrm{F}(1,56)=0.633, \mathrm{p}=0.43)$. Ads created with Helvetica were generally regarded as more preferable $(\mathrm{M}=4.78, \mathrm{SD}=0.771)$, then those without it $(\mathrm{M}=4.52, \mathrm{SD}=0.784)$.

The other goal for preference assessment was to define whether Helvetica in brand logo influence the preference toward ad and brand. It is worth noticing that ad created with Helvetica in category of denim was the only one without Helvetica in brand logo, therefore the results of preference assessment of denim ads were omitted in further evaluation. Mean values of preference grades from other three categories were taken into account for this analysis. Results of MANCOVA analysis, conducted in the same manner as for previous assessment, showed that presence of Helvetica in brand did not have any impact to ad or brand preference. Same stands for gender and former typographical knowledge.

In preference assessment the goal was also to determine the possible relation between attitude toward the ad and the brand, and whether the preferences toward certain brand leads to preferences toward corresponding ad. In order to define possible relation we calculated Pearson coefficient of linear correlation between the preference rates given to an ad and brand, with or without Helvetica in the ad. Results obtained from rating the preference in form I prefer-I do not prefer are used for each ad category and also for all the ads (mean value from all categories).

In the sporting goods and extreme sports equipment category strong positive correlation was found between attitude toward ad and brand when ad was designed with Helvetica $(\mathrm{r}=0.661, \mathrm{p}<0.0005)$. This leads to the conclusion that the high degree of preference toward brand follows the strong preference toward the corresponding ad. Same was noted when ads without Helvetica were assessed $(\mathrm{r}=0.638, \mathrm{p}<0.0005)$.

Strong positive correlation exists also for the results of the ads for shoes assessment. Here, the Pearson coefficient is almost identical no matter if Helvetica was or was not used in the ad $(0.603, \mathrm{p}<0.0005$ and $r=0.691, p<0.0005$, respectively). In denim category same trend was found. If the Helvetica was used for ad design the correlation coefficient was 0.709 $(\mathrm{p}<0.0005)$, while in the other case it was somewhat lower $(\mathrm{r}=0.618, \mathrm{p}<0.0005)$. When preference was assessed for ready-wear ads there moderate correlation found for ads with Helvetica $(\mathrm{r}=0.450, \mathrm{p}<0.0005)$, while for ads without Helvetica moderate correlation exist between preference toward the ad and the brand $(\mathrm{r}=0.576, \mathrm{p}<0.0005)$.

When assessing the preference results for all ads in total, strong positive correlation between ad and brand preference exist if Helvetica is used for creating ad $(\mathrm{r}=0.74, \mathrm{p}<0.0005)$, but also in the case when it was not $(\mathrm{r}=0.803, \mathrm{p}<0.0005)$. We can conclude that the preference toward the brand certainly has very strong impact on preferences of corresponding ad regardless of the typeface used for ad design.

These relations were also assessed in the case where Helvetica was used in brand logo. Results for denim ads were omitted since the brand didn't use Helvetica in its logo design. Mean values of preference rates for three other categories were taken into account (preference rates for individual categories were estimated in the previous case since all the other ads had Helvetica both in brand and in ad). In this case strong positive correlation exists between preference toward ad and brand if brand logo was created with Helvetica $(\mathrm{r}=0.676, \mathrm{p}<0.0005)$, but also if it was not $(\mathrm{r}=0.755$, $\mathrm{p}<0.0005)$. In this manner brand preference was even more emphasized and its influence on ad preference should not be neglected in any case.

\section{Discussion}

One of the criterions for the good typography is the social issue which brings Helvetica up to the level of the brand, a kind of a convention and a dogma. Perhaps it is due to this phenomenon of mass hysteria caused by the Helvetica brand that many companies decide to use Helvetica when giving shape to their visual identities. Using a famous brand to shape their own, they expect a positive transfer which breeds success. A brand has the task of ensuring quality with every purchase, enable easier decision-making and reduce the risk of buying a product of undesirable quality. Because of this, it appears that Helvetica has the task of ensuring quality when shaping the graphic products and provide a sense of security in both the consumers and the manufacturers who consider that the usage of Helvetica is best for their own promotion. It increases the value of a trade mark and/or a designer product because it acts as a quality assurance which influences the value of the brand. The image a brand carries with itself is one of the essential values of the brand to the consumer. The image Helvetica carries 
instigates the usage of epithets such as simple, clear, fast and efficient but stable and reliable. Helvetica is the synonym for quality and timelessness, an origin rooted over the years of using it in shaping some of the most stable and famous world brands.

Mass usage of Helvetica in manufacturing a visual identity of a brand or promotional material brings into question whether Helvetica affects the consumers' response. If so, is it always in positive, or at least neutral, manner as we can see that this typeface can influence the success of the advertising campaign and create a tool with which the companies protect themselves from negative image and bad promotion caused by an inadequate promotional campaign and visual identity.

The results revealed that Helvetica does not cause more positive emotional response in relation to other typefaces in print advertisements. In other words, Helvetica is not "an emotional typeface". Even though this typeface has renewed its popularity and today represents a new type convention for youthful trendy image, we can't say that this typeface has been assigned a new persuasive capacity. The potential of this typeface's visual rhetoric is unchanged. The intentional neutral rhetoric of the international style is less emotional even today in comparison to script and display typeface.

The brand awareness, as its significant dimension, increases the provided value to the consumers. As Veljković and Đorđević (2009) puts it, the most influential scholars in the field of brand management emphasize the importance of directing marketing efforts in forming the brand image or logo which, consequently, will affect the perceived image in the mind of the consumer and distinguish it from the competitor's image (see Keller et al., 2008, p.174; Aaker, 2009,p.181-205). Additionally, Veljković and Đorđević (2009) points on the empirical findings of Baldauf, Cravens, and Binder (2003; cf. Yoo, Donthu, \& Lee, 2000) which indicate that brand awareness i.e. recognition of symbols or logos has an impact on consumers by increasing the perceived value they will receive by purchasing branded products. However, when analyzing the effects of Helvetica on the brand and ad attitudes it was established that there is no particular effect related to brand attitude, while the ads designed with Helvetica really did get higher grades in comparison to other ads. This is understandable as there is an array of factors affecting brand attitude and the connection be- tween the brand and the consumer becomes increasingly profound and leans on the previous experience and emotions related to the brand, so it is often impossible to discern between the value of the brand to the consumer and the brand equity relying only on its visual representation. Brands used in the research were familiar to participants. Further research can be built on unfamiliar brands and we could examine how customers form an attitude toward the ad they see for the first time. An attitude toward the ad, on the other hand, was influenced by Helvetica which can be seen from the results where the advertisements with Helvetica were better rated and more favoured.

The findings indicate that different brand groups have different influence on consumers, as we can see that Helvetica won't produce the best reaction but it will not be strongly unfavourable as well. The trend we see in everyday life is confirmed through this study. There is a specific group of people that recognizes and uses the brand Helvetica in everyday life. People from this group will intentionally choose the products that have Helvetica mark on them. This is the case for the denim and the footwear brands, such as Bench, Superdry, American Apparel, Desigual, and many others. All of $s$ brand have a logo and advertisements, increasingly websites as well, designed with Helvetica. A common thing for all these brands is their target group. They all speak to younger, urban and modern generation. When you wear a piece of clothing signed by one of these names you stand out in the crowed of "ordinary people". You reveal your attitudes toward music, art, culture, politics, and people can even "read" what profession you're in just by looking at your clothes. The strength of Helvetica lies in this reality, in its symbolic meaning. We did confirm that Helvetica is not always the best choice for advertising, but we need to have in mind the target group and the people we want to reach with Helvetica designed message. The textile and fashion industry should consider these findings as they can help build stronger image of the company. The first thing about brand's significance is the image they give to specific, targeted, groups of customers allowing them to meet the needs of belonging, self-affirmation and social intelligence. When we choose certain brand we tell a lot about ourselves to the world, the fact a lot of advertisers use to make a profit and gain popularity. It is not necessary for the brands to provide a quality or durability, but they do have to represent you. 


\section{CONCLUSION}

Most of the designers are unaware of the impact Helvetica has when they use it for a design project. This typeface presents a tradition in the graphic design profession, hence shaping the way we see this profession today. It is a personification of the clean, sharp and simple design with a focus on the content and the message and not the form and decoration. It is used because it simplifies and accelerates work, it looks good on almost every visual material, but how many people will stop and consider why this is so. The strength of the brand Helvetica grows over time; however, there is a possibility, as we've seen in the past, that the popularity of the brand will decrease due to unoriginality and market saturation.

Still, we can't ignore vast number of visual projects which focus is not brand or service promotion but the message transfer and spatial application. Universality and neutrality are a priority in such cases. Together with traffic signs, public space signs and fill-in forms, and with the internet expansion Helvetica is used for a number of websites. We can conclude that sooner or later this typeface will conquer all of the internet and modern-type devices.

Like it or not, its presence is unquestionable. It is practically everywhere. It is on the first place on the list of the world's top seller fonts. Ideally, we can use it when we want to avoid personal touch and stay in the zone of universality. We can't relate this type to any place or a moment in time. However, times have changed in the marketing world. Designers and advertiser nowadays use Helvetica to communicate to younger generations and to give a message modern feel. Along with neutrality, this type takes on particular distinctive features in order to stay in touch with young people and the modern world.

\section{References:}

1. Author (2013)

2. Author (2013)

3. Author (2011)

4. Aaker DA (2009), Managing brand equity: capitalizing of the value of a brand name. New York, The Free Press.

5. Baldauf A, Cravens KS and Binder G (2003), "Performance consequences of brand equity management: evidence from organizations in the value chain". Journal of product \& brand management, MCB UP Ltd, Vol.12, No.4, pp. 220-236.

6. Bartram D (1982), "The perception of semantic quality in type: Differences between designers and non-designers". Information design journal, John Benjamins Publishing Company, Vol. 3, No.1, pp. 3850.

7. Bradley MM., \& Lang PJ (1994), “Measuring emotion: The self-assessment manikin and the semantic differential". Journal of behavior therapy and experimental psychiatry, Vol.25, No.I, pp. 49-59.

8. Brumberger E (2003a), "The rhetoric of typography: The awareness and impact of typeface appropriateness". Vol.50, No.2, pp. 224-231.
9. Brumberger E (2003b), “The rhetoric of typography: The persona of typeface and text". Technical communication, Vol.50, No.2, pp. 206-223.

10. Childers TL and Jass J (2002), "All Dressed Up With Something to Say: Effects of Typeface Semantic Associations on Brand Perceptions and Consumer Memory". Journal of Consumer Psychology, Vol.12, No.2, pp. 93-106.

11. Davis RC and Smith HJ (1933), "Determinants of feeling tone in type faces. Journal of Applied Psychology", American Psychological Association, Vol.17, No.6, p. 742.

12. Doyle JR and Bottomley P a. (2006), "Dressed for the Occasion: Font-Product Congruity in the Perception of Logotype. Journal of Consumer Psychology", Vol.16, No.2, pp. 112-123.

13. Fox D, Shaikh AD and Chaparro BS (2007), The effect of typeface appropriateness on the percepton of documents. In: Proceedings of the Human Factors \& Ergonomics Society 51st Annual Conference, USA, pp. 464-468. 
14. Henderson PW, Giese JL and Cote JA (2004), "Impression management using typeface design". Journal of Marketing, Vol.68, pp. 60-72.

15. Holbrook MB and Batra R (1987), "Assessing the role of emotions as mediators of consumer responses to advertising“. Journal of consumer research, Vol.14, No.3, pp. 404-420.

16. Hustwit G (2007), Helvetica [Film].Brooklyn, NY: Plexi Productions, LLC.

17. Kastl AJ and Child IL (1968), "Emotional meaning of four typographical variables". Journal of Applied Psychology, Vol.52, No.52, pp. 440-446.

18. Kaya N and Epps HH (2004), "Color-emotion associations: Past experience and personal preference". In: AIC 2004 Color and Paints, Interim Meeting of the International Color Association, Proceedings, pp. 31-34.

19. Keedy J (2003), Design Modernism 8.0.Emigre, Rant, No.64, pp. 57-71.

20. Keedy J (1995), Zombie Modernism.Emigre, The Rebirth of Design, No.34, pp. 17-39.

21. Keller KL, Apéria T and Georgson M (2008), Strategic brand management: a European perspective. Harlow, England, Pearson Education.

22. Lang A, Wise K, Lee S, and Cai X (2003), The effects of sexual appeals on physiological, cognitive, emotional, and attitudinal responses for product and alcohol billboard advertising. In: Reichert T, and Lambiase J (eds), Sex in advertising: Perspectives on the erotic appeal. Routledge, 107-132.

23. Lang PJ (1980), Behavioral treatment and biobehavioral assessment: Computer applications. In: Sidowski JB, Johnson JH, and Williams TA (eds), Technology in Mental Health Care Delivery Systems, Ablex Pub. Corp., pp. 119-137.

24. Mackiewicz J and Moeller R (2004), Why people perceive typefaces to have different personalities. In: International Professional Communication Conference, 2004. IPCC 2004. Proceedings.,Ieee, pp. 304-313.

25. McCarthy MS and Mothersbaugh DL (2002), "Effects of typographic factors in advertising-based persuasion: A general model and initial empirical tests". Psychology and Marketing, Vol.19, No.7-8, pp. 663-691.

26. Morris JD, Woo C, Geason JA and Kim J (2002), "The power of affect: Predicting intention". Journal of Advertising Research, Vol.42, No.3, pp.7-17.

27. Morrison G (1986), "Communicability of the emotional connotation of type". Educational
Communication and Technology, Vol.34, No.4, pp. 235-244.

28. Poffenberger a. T and Franken RB (1923), "A study of the appropriateness of type faces". Journal of Applied Psychology, Vol.7, No.4, pp. 312-329.

29. Rowe CL (1982), "The connotative dimensions of selected display typefaces”. Information design journal, John Benjamins Publishing Company, Vol.3, No.1, pp. 30-37.

30. Russell JA and Mehrabian A (1977), "Evidence for a three-factor theory of emotions". Journal of Research in Personality, Vol.11, No.3, pp. 273-294.

31. Schiller G (1935), "An experimental study of the appropriateness of color and type in advertising". Journal of Applied Psychology, Vol.19, No.6, p. 652.

32. Secrest JM (1947), "Personalities in type designs". Printer's ink, No. 218, pp. 52-53.

33. Starkweather JA (1956), “The communication-value of content-free speech". The American Journal of Psychology, Vol.69, No.1, pp. 121-123.

34. Tannenbaum PH, Jacobson HK and Norris EL (1964), "An experimental investigation of typeface connotations". Journalism \& Mass Communication, Vol.41, No.1, pp. 65-73.

35. Valdez P and Mehrabian A (1994), "Effects of color on emotions". Journal of Experimental Psychology: General, Vol.123, No.4, pp. 394-409.

36. Vandewalle G, Schwartz S, Grandjean D, et al. (2010), Spectral quality of light modulates emotional brain responses in humans. Proceedings of the National Academy of Sciences, National Acad Sciences, Vol. 107, No.45, pp. 19549-19554.

37. Veljković S, and Đorđević A, (2009), Brand Values for Consumers and Companies, Marketing, Vol. 41, No.1, pp. 3-16.

38. Waltzlawick P, Beavin JH and Jackson DD (1967), Pragmatics of human communication.Educational Theatre Journal, W. W. Norton \& Company, Inc. New York.

39. Wijnholds A de B (1996), Using Type: The Typographer's Craftsmanship and the Ergonomist's Research. Utrecht University, April.

40. Yoo B, Donthu N and Lee S (2000), "An examination of selected marketing mix elements and brand equity". Journal of the Academy of Marketing Science, Vol. 28, No.2, pp. 195-211.

41. van Leeuwen T (2006), "Towards a semiotics of typography”. Information Design Journal, Vol.4, September, pp. 139-155. 


\title{
Sažetak:
}

\section{Helvetika kao tipo konvencija \\ za mladalački i trend imidž: \\ Odgovor potrošača na sigurnu opciju dizajnera}

Uroš Nedeljković, Dragoljub Novaković, Irma Puškarević, Ivana Tomić

U oglašavanju, tipografija se smatra za važan i obavezan element. Jedno od najistaknutijih tipografskih pisama današnjice je svakako Helvetika, čime je ovo pismo odredilo i središte našeg istraživanja. Cilj ovog istraživanja bio je da se ispita konotativno značenje pisma Helvetika, u vremenu u kojem je ovom pismu obnovljena popularnosti. Mi smo ispitivali odgovor potrošača na oglase sa Helvetikom kao dominantnim izražajnim sredstvom. Rezultati ukazuju da emocionalni odgovor na oglase u kojima dominira Helvetika pismo, nije veći u odnosu na oglase oblikovane drugim pismima, što ukazuje na to da Helvetika nije „emocionalno pismo”. Međutim, nalazimo da ispitanici ipak preferiraju oglase koji koriste Helvetiku u oblikovanju slogana, teksta oglasa i logotipa brenda. Zaključujemo da, iako Helvetika danas nakon obnovljene popularnosti predstavlja tipo konvenciju za mladalački i trend imidž, mi ovom pismu ne možemo pripisati nove ubeđivačke atribute.

Ključne reči: Oglašavanje, tipografija, tipografsko pismo, Helvetika, odgovor potrošača, emocionalni odgovor, tipo konvencija.

\section{Kontakt:}

Univerzitet u Novom Sadu, Fakultet tehničkih nauka Departman za grafičko inžinjerstvo i dizajn

\author{
Uroš Nedeljković \\ urosned@uns.ac.rs \\ Dragoljub Novaković \\ novakd@uns.ac.rs \\ Irma Puškarević \\ irma@uns.ac.rs \\ Ivana Tomić \\ tomic@uns.ac.rs
}

